\title{
The Effect of Modified Biolasol Solution on the Efficacy of Storing Isolated Porcine Kidneys
}

\author{
Aneta Ostróżka-Cieślik (D), ${ }^{1}$ Barbara Dolińska, ${ }^{1,2}$ and Florian Ryszka ${ }^{2}{ }^{2}$ \\ ${ }^{1}$ Department of Pharmaceutical Technology, School of Pharmacy and the Division of Laboratory Medicine in Sosnowiec, \\ Medical University of Silesia, Katowice, Poland \\ 2"Biochefa" Pharmaceutical Research and Production Plant, Sosnowiec, Poland \\ Correspondence should be addressed to Aneta Ostróżka-Cieślik; aostrozka@sum.edu.pl
}

Received 21 June 2018; Revised 16 September 2018; Accepted 10 October 2018; Published 12 November 2018

Guest Editor: Maria Irene Bellini

\begin{abstract}
Copyright @ 2018 Aneta Ostróżka-Cieślik et al. This is an open access article distributed under the Creative Commons Attribution License, which permits unrestricted use, distribution, and reproduction in any medium, provided the original work is properly cited.

Biolasol is a newly developed solution for storing the liver, pancreas, kidneys, and heart by simple hypothermia. It exhibits high efficacy in maintaining structural and functional integrity of the graft prior to its transplantation. The solution was modified by the addition of ascorbic acid $(0.088 \mathrm{~g} / \mathrm{l})$ and ascorbic acid with prolactin $(1 \mu \mathrm{g} / \mathrm{l} \mathrm{PRL}+0.088 \mathrm{~g} / \mathrm{l}$ vitamin $\mathrm{C})$. The effectiveness of the obtained solutions in the protection of nephrons of isolated porcine kidneys was assessed based on the analysis of the activity of ALT (alanine aminotransferase), AST (aspartate aminotransferase), and LDH (lactate dehydrogenase) as well as lactate concentration determined in perfundates collected after $2 \mathrm{~h}\left(0^{\prime}\right.$ and $30^{\prime}$ preservation) and $48 \mathrm{~h}\left(0^{\prime}\right.$ and $30^{\prime}$ preservation) of graft storage. It has been found that the synergistic action of Biolasol components determines the integrity and stability of cell membranes, which in turn affects the proper functioning of the organ after transplantation. The addition of ascorbic acid and prolactin to Biolasol affects the maintenance of the normal cytoskeleton of the stored graft.
\end{abstract}

\section{Introduction}

Biolasol is a newly developed solution for storing the liver, pancreas, kidneys, and heart by simple hypothermia. It exhibits high efficacy in maintaining structural and functional integrity of the graft prior to its transplantation. Biolasol is an extracellular fluid with a sodium concentration of $105 \mathrm{mmol} / \mathrm{l}$ and potassium concentration of $10 \mathrm{mmol} / \mathrm{l}$ Dextran70 (colloid osmotic) affects the maintenance of the correct volume of fluids in the intravascular space. Disodium edetate (EDTA) complexes multivalent metal cations. By chelating $\mathrm{Ca}^{2+}$ ions, it blocks the activation of zymogens involved in the coagulation process. In complex with $\mathrm{Fe}^{2+}$ ions, it reduces the risk of damage caused by the activity of the hydroxyl radical formed in the presence of iron with $\mathrm{H}_{2} \mathrm{O}_{2}$ in the Fenton reaction. Iron chelators reduce the release of lipid peroxidation products, which minimizes the inflammatory response and the influx of neutrophils into the graft. Magnesium fumarate minimizes cell damage during ischemia and reperfusion. Sodium bicarbonate functions as a buffer system and helps maintain the proper acid-base balance. Glucose is involved in the renewal of ATP [1-4]. Table 1 compares the composition of Biolasol with other fluids available on the world market [5].

Biolasol limits the effects of organ ischaemia and prevents its dysfunctions resulting from rapid cooling. Oxygen deficiency and the switch of cells to anaerobic metabolism reduce ATP reserves and impair the sodium-potassium pump. There occurs an uncontrolled inflow of sodium and calcium to the cell. $\mathrm{Ca}^{2+}$-dependent proteases and phospholipases are activated causing lysis of the cell membrane and damage to ion channels. A decrease in $\mathrm{pH}$, lactate accumulation, and inhibition of oxidative phosphorylation are also observed. Free oxygen radicals are generated, including the superoxide radical, which is toxic to the lipid membranes of the cell and damages the structure of proteins and enzymes. As a consequence, it can lead to severe damage to organs. Biolasol enables restoring their proper functioning after transplantation [1-6]. 
TABLE 1: Composition of preservation solutions.

\begin{tabular}{|c|c|c|c|c|c|}
\hline Component & Biolasol & Viaspan & IGL-1 & HTK & Celsior \\
\hline IC/EX & EX & IC & $\mathrm{EX}$ & $\mathrm{EX}$ & EX \\
\hline \multicolumn{6}{|l|}{$\begin{array}{l}\text { Electrolytes } \\
(\mathrm{mmol} / \mathrm{l})\end{array}$} \\
\hline Potassium & 10 & 125 & 25 & 10 & 15 \\
\hline Sodium & 105 & 29 & 120 & 15 & 100 \\
\hline Calcium & 0.5 & - & - & 0.015 & 0.25 \\
\hline Magnesium & 5 & 5 & 5 & 4 & 13 \\
\hline Chloride & 10.5 & 20 & - & 32 & 42 \\
\hline \multicolumn{6}{|l|}{ Colloids (g/L) } \\
\hline HES & - & 50 & - & - & - \\
\hline PEG-35 & - & - & 1 & - & - \\
\hline Dextran 70 & 0.7 & - & - & - & - \\
\hline \multicolumn{6}{|l|}{$\begin{array}{l}\text { ROS scavengers } \\
(\mathrm{mmol} / \mathrm{l})\end{array}$} \\
\hline Allopurinol & - & 1 & 1 & - & - \\
\hline Glutathione & - & 3 & 3 & - & 3 \\
\hline Mannitol & - & - & - & 30 & 60 \\
\hline Tryptophan & - & - & - & 2 & - \\
\hline \multicolumn{6}{|l|}{ Buffers (mmol/l) } \\
\hline Histidine & - & - & - & 198 & 30 \\
\hline $\mathrm{KH}_{2} \mathrm{PO}_{4}$ & - & 25 & 25 & - & - \\
\hline $\mathrm{NaHCO}_{3}$ & 5 & - & - & - & - \\
\hline \multicolumn{6}{|l|}{$\begin{array}{l}\text { Impermeants } \\
(\mathrm{mmol} / \mathrm{l})\end{array}$} \\
\hline Citrate & 30 & - & - & - & - \\
\hline Glucose & 167 & - & - & - & - \\
\hline Lactobionate & - & 100 & 100 & - & 80 \\
\hline Raffinose & - & 30 & 30 & - & - \\
\hline \multicolumn{6}{|l|}{ Additives (mmol/l) } \\
\hline Adenosine & - & 5 & 5 & - & - \\
\hline EDTA & 5 & - & - & - & - \\
\hline Fumarate & 5 & - & - & - & - \\
\hline Glutamic acid & - & - & - & - & 20 \\
\hline Ketoglutarate & - & - & - & 1 & - \\
\hline Insulin (U/l) & - & 40 & - & - & - \\
\hline $\begin{array}{l}\text { Dexamethasone } \\
(\mathrm{mg} / \mathrm{l})\end{array}$ & - & 16 & - & - & - \\
\hline Penicillin G (UI/l) & - & $2-00$ & - & - & - \\
\hline $\mathrm{pH}$ & 7.4 & 7.4 & 7.4 & 7.20 & 7.3 \\
\hline Viscosity & Low & High & High & Low & Low \\
\hline Osmolality & 330 & 320 & 290 & 310 & $320-360$ \\
\hline $\mathrm{mOsm} / \mathrm{kg} \mathrm{H}{ }_{2} \mathrm{O}$ & & & & & \\
\hline
\end{tabular}

IC: intracellular, EX: extracellular.

A number of clinical trials were carried out to assess the effectiveness of Biolasol, also in relation to commonly used perfusion and organ preservation fluids. Its effectiveness was not worse than that of HTK, UW, and Viaspan fluids. Biolasol protects grafts against ischemic damage in a similar way as the aforementioned solutions. It has been found that Biolasol provides better homeostasis of isolated porcine kidneys during storage compared to the HTK solution [2]. Jóźwik et al. [7] transplanted into patients 42 kidneys which had previously been rinsed and stored in Biolasol and UW solutions. They demonstrated comparable effectiveness of both fluids [7]. Cierpka et al. performed comparative 
studies of the effectiveness of Biolasol and Viaspan in the procedure of kidney autotransplantation in 12 pigs. They have shown that the used solutions protect the kidneys from ischemia-reperfusion injury in a similar way [3]. Based on our histopathological examinations, we have found that adding prolactin to the HTK preservation fluid minimizes hepatocyte damage in the model using an isolated rabbit liver [8]. Cierpka et al. confirmed by means of histopathological examination that the structure of the isolated porcine kidney cortex was not damaged after using Biolasol [1].

Biolasol was modified by the addition of ascorbic acid and ascorbic acid with prolactin. Prolactin, a hormone secreted by pituitary cells, and an exogenous antioxidant, vitamin $\mathrm{C}$, were used in the modification. Ascorbic acid plays an important role in maintaining the appropriate oxidationreduction potential in cells and neutralizes the reactive forms of oxygen and nitrogen resulting from cellular metabolism. It occurs both outside and inside the cells. The normal concentration of ascorbic acid in the plasma is over $17 \mu \mathrm{mol} / \mathrm{l}$, usually $45-80 \mu \mathrm{mol} / \mathrm{l}$, whereas in leukocytes and platelets it is approximately $1480 \mu \mathrm{mol} / \mathrm{l}$. In turn, prolactin (PRL) is a protein hormone and a strong cytokine with a broad spectrum of biological activities. It acts as an immunoregulator in cell proliferation and differentiation and is an apoptosis inhibiting factor. It enhances the expression of IL2 receptors on lymphocytes and stimulates the production of antibodies by B-lymphocytes. It affects the production of lysozyme and lowers the high ceruloplasmin level induced by inflammatory reactions $[9,10]$. Ryszka et al. administered prolactin subcutaneously at a dose of $25 \mu \mathrm{g} / \mathrm{kg}$ of body weight in rats. They have found that the distribution of prolactin in selected organs and tissues decreases in the following order: milk gland $>$ blood $>$ pituitary $>$ ovaries $>$ lungs $>$ liver $>$ cranial bone $>$ spleen $>$ heart $>$ kidneys $>$ muscular tissue $>$ adenose $>$ adipose tissue $>$ brain [11]. Prolactin acts by means of specific PRLRs, belonging to type I cytokine transmembrane receptors. Specific PRLRs are located at various places in cells and tissues [12]. The presence of PRL receptors was found in the proximal renal tubules and in the nephron, in the thick section of the ascending arm of the Henle loop, and in the distal tubule and the collecting duct [13]. Ibarra et al. have found that PRL is a natriuretic hormone that interacts with the renal dopaminergic system in inhibiting $\mathrm{Na}+, \mathrm{K}+$, and ATP-ase in the proximal renal tubules [14]. Prolactin may affect the filtration rate in the renal glomerulus and the renal plasma flow [15]. It has also been found to affect the proliferation of renal tubular epithelium [16]. It is suggested that PRL receptors are also located in the three zones (cytoplasm of cells, zona glomerulosa, and zona fasciculata) of the adrenal cortex [17].

An important consequence of renal ischaemia is the disorder of apoptosis and repair processes within the renal tubules. The loss of integrity of the cytoskeleton of cells, detachment of the brush border of the proximal tubules, and disturbance of expression of adhesion particles are observed. The $\mathrm{C} 3$ segment of the proximal tubule of the nephron and the thick ascending limb of Henle's loop are the most sensitive to ischemia. Damaged cells of the tubules peel off and clog the lumen of the tubules, which causes leakage of filtrate into the lumen of the capillary vessels and a decrease in glomerular filtration [18].

The effectiveness of the modified Biolasol fluid in the protection of nephrons from the effects of ischemia and hypoxia was assessed based on the study of aminotransferase activity, LDH activity, and lactate concentration in the perfusates taken from the renal vein. AST and ALT belong to cellular enzymes, whose increased activity correlates with the increased permeability of cell membranes and/or indicates the breakdown of cells. Aspartate aminotransferase is in 30\% present in the tissues of the body as a cytoplasmic isoform (AST1) and in $70 \%$ as a mitochondrial isoform (AST2). The increase in its activity is mainly related to the damage of mitochondrial membranes. In turn, alanine aminotransferase is produced in the renal tubular epithelium, and its increased activity indicates damage to the cytoplasmic membranes. Lactate dehydrogenase is located in the cytoplasm of the cell, and its activity increases when cell/tissue necrosis occurs [19]. Lactates are produced in the tissues of the whole body in the process of anaerobic glycolysis. The amount of released $\mathrm{LDH}$ and lactates indicates the degree of acidification of the intracellular environment. The determined values of the abovementioned markers in perfusate samples may be helpful in determining the extent of kidney damage during storage $[20,21]$.

The aim of the study was to evaluate the modified Biolasol solution in terms of the protection of nephrons of isolated porcine kidneys based on the analysis of the activity of ALT (alanine aminotransferase), AST (aspartate aminotransferase), and LDH (lactate dehydrogenase) as well as lactate concentration determined in perfundates collected after $2 \mathrm{~h}$ and $48 \mathrm{~h}$ of graft storage.

\section{Materials and Methods}

The study used Biolasol solution (FZNP "Biochefa", Poland) and Biolasol modified by the addition of porcine prolactin - $1 \mu \mathrm{g} / \mathrm{l}$ (FZNP "Biochefa", Poland) and/or ascorbic acid 0.088g/l (PLIVA Pharmaceutical Company, Cracow, Poland). The study used 30 kidneys from 15 adult Great White Poland pigs weighing 90-110 kg, aged 175-180 days. The kidneys were collected in the slaughterhouse of the Meat Plant H.A.M in Radzionków. After collection, the kidneys were cannulated and stored in a suitable preservation solution (Biolasol, Biolasol+vit.C, or Biolasol+vit.C+PRL) at $4^{\circ} \mathrm{C}$ for 2 hours (it was the time necessary to transport the organ from the slaughterhouse of H.A.M Meat Plant in Radzionków to the laboratory). The kidneys were then rinsed under the pressure of $73,5 \mathrm{mmHg} \mathrm{H}_{2} \mathrm{O}$ with the following solutions: Biolasol, Biolasol + vit.C, and Biolasol + PRL + vit.C. The perfusate samples were collected from the kidney vein at 0 and 30 minutes of perfusion. After 30 minutes, the kidneys were cooled and placed in a sterile bag filled with $500 \mathrm{ml}$ of appropriate preservation solution (Biolasol, Biolasol+vit.C, or Biolasol+vit.C+PRL) for 48 hours (maximum time of organ storage in Biolasol). After this time, activities related to renal perfusion were repeated. In the perfusate samples, the activity of the released indicator enzymes, namely, aspartate aminotransferase (AST), alanine aminotransferase (ALT), 


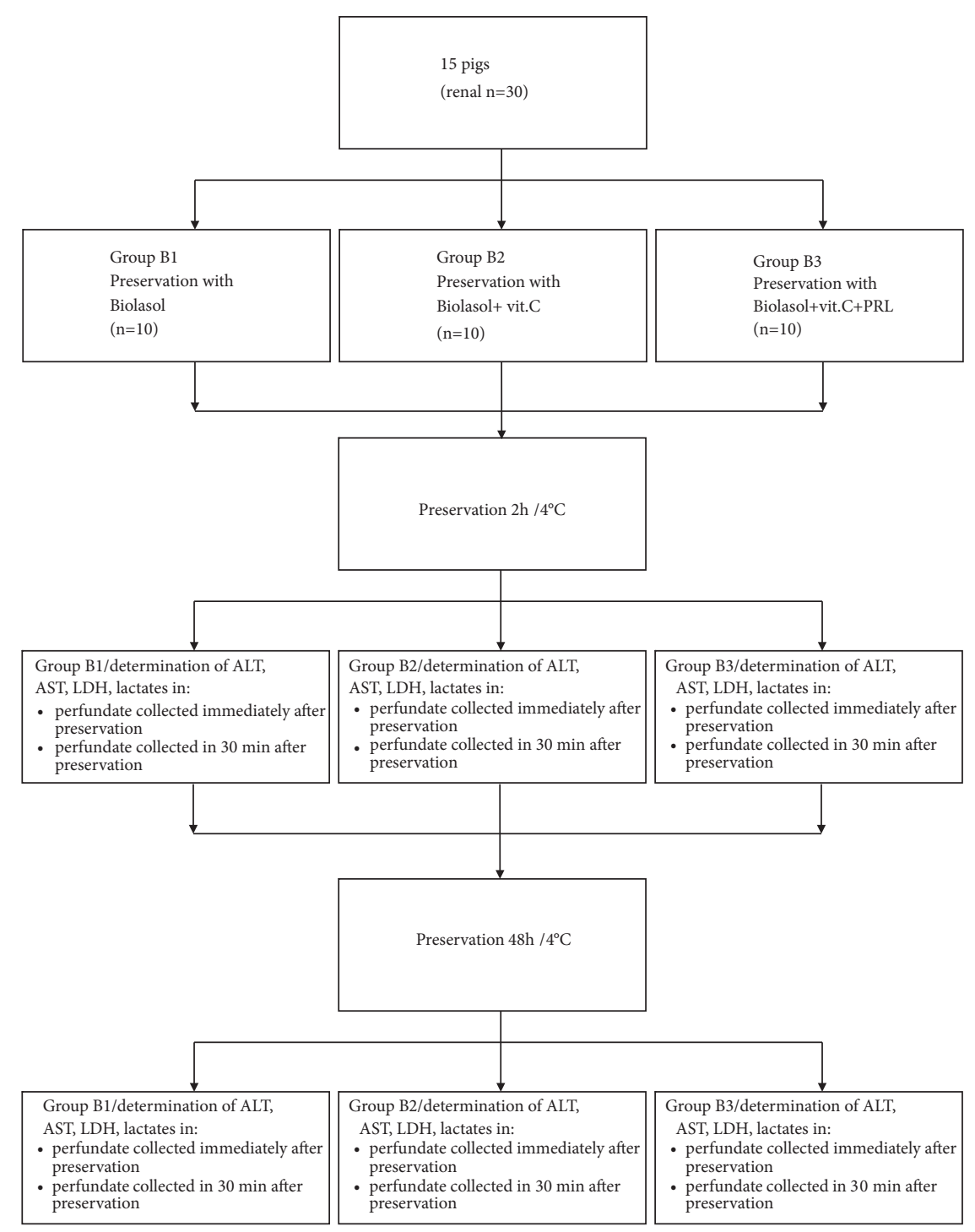

Figure 1: Study design.

and lactate dehydrogenase $(\mathrm{LDH})$, as well as lactate concentration was determined by spectrophotometric methods using the bioMérieux diagnostic kit, Lyon, France (Figure 1).

The normality of the distribution of variables was checked using the Shapiro-Wilk criteria. Comparison among groups was performed using the Kruskal-Wallis test for nonparametric continuous variables, or variance (ANOVA) for parametric continuous variables. The calculations were made using Statistica version 8.0 software (StatSoft, Poland).

\section{Results}

On the basis of the conducted tests (Table 2), it has been found that the increase in AST activity in the modified solution perfusates is accompanied by a marked lower increase in ALT activity, which translates into the ratio of the activity of these enzymes in porcine serum under physiological conditions (AST - 32-84 U/1, ALT - 31-58 U/1) [2]. It has also been observed that, after 2 hours of storage, both in perfusates of
Biolasol modified with the addition of vitamin $\mathrm{C}$ and Biolasol modified with the addition of vit.C and PRL, ALT activity remained at the physiological level: $34.7 \mathrm{U} / 1$ vs. $43.7 \mathrm{U} / 1$. After $48 \mathrm{~h}$ of storage, there was a slight decrease in ALT activity in both cases: $29.6 \mathrm{U} / \mathrm{l}(\sim 14.7 \%)$ vs. $43.2 \mathrm{U} / 1(\sim 1.1 \%)$. The difference is not significant. The obtained results of alanine aminotransferase activity are lower compared to its activity in Biolasol solution perfusates (70.6 U/1-2h, $68.6 \mathrm{U} / \mathrm{l}-48 \mathrm{~h})$. The difference is not significant.

Aspartate aminotransferase (AST) activity remained at the physiological level in the perfusates of all analysed solutions after 48 hours of renal storage. An increase in this parameter was observed after $2 \mathrm{~h}$ of storing the graft in Biolasol modified with the addition of vit.C and PRL $103.4 \mathrm{U} / \mathrm{l}(\sim 18.8 \%$ vs. norm $84 \mathrm{U} / \mathrm{l})$. This may indicate that nephrons were damaged in the early period of kidney storage, presumably as a result of increased expression of prolactin receptors. After 2 hours of $30^{\prime}$ preservation using Biolasol modified with the addition of ascorbic acid and prolactin, 
TABLE 2: Biochemical parameters of the efficacy of storing kidneys in Biolasol and Biolasol -modified solutions with the addition of ascorbic acid and prolactin \pm SD.

\begin{tabular}{|c|c|c|c|c|}
\hline Time [min] & $\begin{array}{c}\text { Biolasol } \\
\text { (control } \\
\text { group) }\end{array}$ & $\begin{array}{c}\text { Biolasol } \\
\text { +vit.C } \\
\text { (experimental } \\
\text { group) }\end{array}$ & $\begin{array}{c}\text { Biolasol } \\
+ \text { PRL+vit.C } \\
\text { (experimental } \\
\text { group) } \\
\end{array}$ & Significance \\
\hline & & ALT [U/l] & & \\
\hline $2 \mathrm{~h}$ preservation $0^{\prime}$ & $70.6 \pm 19.0$ & $34.7 \pm 4.9$ & $43.7 \pm 16.6$ & NS \\
\hline $2 \mathrm{~h}$ preservation $30^{\prime}$ & $58.8 \pm 15.5$ & $21.0 \pm 4.6$ & $24.3 \pm 9.1$ & NS \\
\hline $48 \mathrm{~h}$ preservation $0^{\prime}$ & $68.6 \pm 16.9$ & $29.6 \pm 7.3$ & $43.2 \pm 11.2$ & NS \\
\hline \multirow[t]{2}{*}{$48 \mathrm{~h}$ preservation $30^{\prime}$} & $60.1 \pm 17.9$ & $12.8 \pm 4.9$ & $24.1 \pm 9.0$ & $\mathrm{P}<0.05$ \\
\hline & & AST [U/l] & & \\
\hline $2 \mathrm{~h}$ preservation $0^{\prime}$ & $60.5 \pm 16.4$ & $54.3 \pm 14.0$ & $103.4 \pm 34.6$ & NS \\
\hline $2 \mathrm{~h}$ preservation $30^{\prime}$ & $32.6 \pm 8.9$ & $34.9 \pm 13.6$ & $63.9 \pm 16.8$ & NS \\
\hline $48 \mathrm{~h}$ preservation $0^{\prime}$ & $60.3 \pm 11.1$ & $48.0 \pm 18.7$ & $63.8 \pm 17.5$ & NS \\
\hline \multirow[t]{2}{*}{$48 \mathrm{~h}$ preservation $30^{\prime}$} & $35.8 \pm 9.4$ & $18.0 \pm 6.0$ & $36.0 \pm 12.3$ & NS \\
\hline & & $\mathrm{LDH}[\mathrm{U} / \mathrm{l}]$ & & \\
\hline $2 \mathrm{~h}$ preservation $0^{\prime}$ & $720.8 \pm 164.6$ & $444.8 \pm 195.1$ & $602.0 \pm 171.0$ & NS \\
\hline $2 \mathrm{~h}$ preservation $30^{\prime}$ & $168.1 \pm 41.4$ & $313.2 \pm 112.1$ & $305.7 \pm 161.0$ & NS \\
\hline $48 \mathrm{~h}$ preservation $0^{\prime}$ & $416.0 \pm 59.9$ & $475.0 \pm 113.0$ & $473.0 \pm 95.4$ & NS \\
\hline \multirow[t]{2}{*}{$48 \mathrm{~h}$ preservation $30^{\prime}$} & $216.5 \pm 135.5$ & $129.5 \pm 54.9$ & $145.7 \pm 71.0$ & NS \\
\hline & & $\begin{array}{l}\text { Lactates } \\
{[\mathrm{mmol} / \mathrm{l}]}\end{array}$ & & \\
\hline $2 \mathrm{~h}$ preservation $0^{\prime}$ & $0.9 \pm 0.3$ & $1.2 \pm 0.2$ & $1.2 \pm 0.4$ & NS \\
\hline $2 \mathrm{~h}$ preservation $30^{\prime}$ & $0.5 \pm 0.1$ & $0.5 \pm 0.2$ & $0.2 \pm 0.1$ & NS \\
\hline $48 \mathrm{~h}$ preservation $0^{\prime}$ & $1.0 \pm 0.4$ & $0.9 \pm 0.3$ & $1.5 \pm 0.7$ & NS \\
\hline $48 \mathrm{~h}$ preservation $30^{\prime}$ & $0.6 \pm 0.2$ & $0.5 \pm 0.3$ & $0.2 \pm 0.1$ & NS \\
\hline
\end{tabular}

Comparisons between the three groups were performed by analysis of variance (ANOVA) or the Kruskal-Wallis test.

the AST activity decreased by $38 \%$. Rinsing the blood off the organ might have resulted in the restoration of intracellular calcium homeostasis and improvement of mitochondrial cell activity [22, 23].

The physiological norm of lactate dehydrogenase activity in porcine serum is 380-634 U/1 [2]. After 48 hours of storage, LDH activity determined in the perfusates of all solutions oscillates within the normal range. A slight increase in $\mathrm{LDH}$ activity $(\sim 12 \%)$ was reported after 2 hours of storing the kidneys in Biolasol solution.

Metabolic acidosis is caused by an increase in serum lactate level above $2 \mathrm{mmol} / \mathrm{l}$. In all the analysed perfusate samples, the lactate concentration was within the normal range. The lowest concentration of this parameter was determined in the perfusates of Biolasol modified with the addition of vit.C and PRL at 30 minutes of perfusion after $2 \mathrm{~h}$ and $48 \mathrm{~h}$ of storage $(0.2 \mathrm{mmol} / \mathrm{l})$.

\section{Discussion}

High aminotransferase activity, LDH activity, and an increase in lactate concentration may indicate renal ischemic damage and may correlate with the loss of secretory function after transplantation $[2,21,24]$. A similar relationship has been observed by $\mathrm{Li}$ et al. [25]. Hypoxia of renal tubule cells during cold ischaemia results in a significant $\mathrm{LDH}$ release
[26]. Renal damage also causes the release of AST and ALT located in the proximal tubule $[27,28]$. The abovementioned parameters were significantly reduced during preservation in Biolasol, Biolasol + vit.C, and Biolasol + vit.C + PRL. Biolasol solution and its modifications were used in maintaining the structural and functional integrity of kidneys under hypoxic conditions. One of the possible protective mechanisms may be an antioxidant effect.

Prolactin, besides fulfilling many biological functions, has a pleiotropic effect. On the basis of the conducted research, it is supposed that PRL participates in the removal of free oxygen radicals (ROS) generated in the cellular space. At present, the mechanism of its operation in this aspect is unknown [29]. It is suggested that PRL may act as an antioxidant in enhancing endogenous antioxidants [29]. It has been found that prolactin indirectly influences the increase of glutathione (GSH) concentration in the cell by stimulation of, e.g., transcription factors, including those regulating insulin secretion. This increase may result from increased glutamatecysteine ligase (GCL) activity, which catalyses the key step of GSH synthesis [30, 31]. The results of our research suggest that PRL may also exhibit a synergistic effect with exogenous antioxidants, i.e., vitamin C.

The obtained parameters suggest a positive effect of ascorbic acid on the integrity of the cytoskeleton of the stored graft. During ischemia, the formation of reactive oxygen 
species (ROS) is activated, which reduces the effectiveness of antioxidative systems. With a large amount of ROS, lipid peroxidation reactions, which are one of the causes of cellular damage, are triggered. Polyunsaturated fatty acids included in phospholipids, which are the building blocks of cell membranes, undergo peroxidation [32]. Supplementing the liquid with an exogenous antioxidant in the form of ascorbic acid supports the weakened graft antioxidant system. Consequently, vitamin $\mathrm{C}$ reduces the formation of ROS and has a protective effect on cell integrity. Lloberas et al. carried out research which has shown that the administration of vitamin $\mathrm{C}$ during kidney transplantation in a rabbit reduces the concentration of lipids and myeloperoxidase and improves organ function [33]. It has been noted that the administration of vitamin $\mathrm{C}$ during kidney transplantation in humans significantly reduces damage caused during reperfusion [34]. In addition, it has been found that preservation solutions modified with vitamin $\mathrm{C}$ are more durable [35].

Prolactin may indirectly affect the dilation of renal vessels and, as a consequence, increase the glomerular filtration rate [36]. It is suggested that PRL blocks the inflow of $\mathrm{Ca}^{2+}$ to the inside of the cells. Increased calcium concentration in the cell results in the activation of intracellular enzymes that cause the degradation of phospholipids and increase the permeability of the cell membrane.

A number of our studies indicate the hepatoprotective and nephroprotective effects of prolactin $[8,20,21]$. PRL protects the structure and function of cells against the negative effects of ischemia and hypoxia [20,37]. The addition of this hormone to preservation solutions affects the regeneration of cells after hepatectomy and nephrectomy. It also ensures the integrity of the cell membrane and contributes to the maintenance of normal balance of ions and normal morphological parameters of the liver and kidneys [20, 37]. The addition of $1 \mu \mathrm{g} / \mathrm{l} \mathrm{rh}-\mathrm{PRL}$ to Biolasol solution reduces ALT and AST activity during reperfusion [20].

\section{Conclusions}

The synergistic action of Biolasol components determines, inter alia, the integrity and stability of cell membranes, which in turn affects the proper functioning of the organ after transplantation. The addition of ascorbic acid and prolactin to Biolasol solution affects the maintenance of the normal cytoskeleton of the stored graft.

\section{Data Availability}

The data used to support the findings of this study are available from the corresponding author upon request.

\section{Conflicts of Interest}

The authors declare that there are no conflicts of interest regarding the publication of this article.

\section{Acknowledgments}

This work was supported by the European Regional Development Fund under the Operational Programme Innovative Economy no. UDA-POIG.01.04.00-24-002/11-00 “Research on development of production technology of effective kidney transplantation solution," 2011 to 2014.

\section{References}

[1] L. Cierpka, F. Ryszka, B. Dolińska et al., "Biolasol: Novel perfusion and preservation solution for kidneys," Transplantation Proceedings, vol. 46, no. 8, pp. 2539-2541, 2014.

[2] B. Dolińska, A. Ostrózka-Cieślik, A. Caban, L. Cierpka, and F. Ryszka, "Comparing the effect of Biolasol ${ }^{\circledR}$ and HTK solutions on maintaining proper homeostasis, indicating the kidney storage efficiency prior to transplantation," Annals of Transplantation, vol. 17, no. 2, pp. 74-78, 2012.

[3] G. Budziński, A. Suszka-Switek, P. Roman et al., "Interleukin-6 concentration in the transgenic pig's liver preserved for 24 hours in Biolasol solution," Transplantation Proceedings, vol. 46, no. 8, pp. 2552-2554, 2014.

[4] G. Budziński, A. Suszka-Świtek, P. Roman et al., "Cytochrome P450 3 a expression in pigs livers after 24-hour preservation in biolasol solution depending on the type of transgenesis," Transplantation Proceedings, vol. 46, no. 8, pp. 2548-2551, 2014.

[5] A. Ostrózka-Cieslik, B. Dolinska, and F. Ryszka, "Tips for optimizing organ preservation solutions," Acta Biochimica Polonica, vol. 65, no. 1, pp. 9-15, 2018.

[6] P. A. Torres, J. A. Helmstetter, A. M. Kaye, and A. D. Kaye, "Rhabdomyolysis: Pathogenesis, diagnosis, and treatment," The Ochsner Journal, vol. 15, no. 1, pp. 58-69, 2015.

[7] A. Jozwik, P. Domagala, and R. Kieszek, "Storage Kidneys Prior to Transplantation Using First Polish Preservation Solution Biolasol , Preliminary Report," American Journal of Transplantation, vol. 16, no. 3, 2016.

[8] B. Szulc-Musioł, B. Dolińska, K. Jasik, and F. Ryszka, "Effect of Prolactin on Biochemical and Morphological Parameters of Rabbit Liver in Warm Ischemia," Transplantation Proceedings, vol. 50, no. 7, pp. 2229-2234, 2018.

[9] T. Yada, K. Muto, T. Azuma, and K. Ikuta, "Effects of prolactin and growth hormone on plasma levels of lysozyme and ceruloplasmin in rainbow trout," Comparative Biochemistry and Physiology - C Toxicology and Pharmacology, vol. 139, no. 1-3, pp. 57-63, 2004.

[10] A. S. Chang, R. Grant, H. Tomita, H.-S. Kim, O. Smithies, and M. Kakoki, "Prolactin alters blood pressure by modulating the activity of endothelial nitric oxide synthase," Proceedings of the National Acadamy of Sciences of the United States of America, vol. 113, no. 44, pp. 12538-12543, 2016.

[11] F. Ryszka, B. Dolińska, and A. Suszka-Świtek, "Distribution of prolactin in selected rat organs and tissues," International Journal of Tissue Reactions, vol. 24, no. 1, pp. 33-36, 2002.

[12] J. Carretero, V. Sánchez-Robledo, M. Carretero-Hernández et al., "Prolactin system in the hippocampus," Cell and Tissue Research, 2018.

[13] K. Mountjoy, E. A. Cowden, J. W. Dobbie, and J. G. Ratcliffe, "Prolactin receptors in the rat kidney," Journal of Endocrinology, vol. 87, no. 1, pp. 47-54, 1980.

[14] F. Ibarra, S. Crambert, A.-C. Eklöf, A. Lundquist, P. Hansell, and U. Holtbäck, "Prolactin, a natriuretic hormone, interacting with 
the renal dopamine system," Kidney International, vol. 68 , no. 4 , pp. 1700-1707, 2005.

[15] S. E. Morrissey, T. Newth, R. Rees, A. Barr, F. Shora, and J. F. Laycock, "Renal effects of recombinant prolactin in anaesthetized rats," European Journal of Endocrinology, vol. 145, no. 1, pp. 6571, 2001.

[16] J. Michalik and Z. Bartoszewicz, "Prolactin (PRL) a pituitary peptide hormon of multiple functions," Postepy Biochemii, vol. 48, pp. 296-305, 2002.

[17] A. Glasow, M. Breidert, A. Haidan, U. Anderegg, P. A. Kelly, and S. R. Bornstein, "Functional aspects of the effect of prolactin (PRL) on adrenal steroidogenesis and distribution of the PRL receptor in the human adrenal gland," The Journal of Clinical Endocrinology \& Metabolism, vol. 81, no. 8, pp. 3103-3111, 1996.

[18] F. K. Chan, K. Moriwaki, and M. J. De Rosa, "Detection of necrosis by release of lactate dehydrogenase activity," in Immune Homeostasis, vol. 979 of Methods in Molecular Biology, pp. 6570, Humana Press, Totowa, NJ, 2013.

[19] N. Lameire, W. van Biesen, and R. Vanholder, "Acute renal failure," The Lancet, vol. 365, no. 9457, pp. 417-430, 2005.

[20] F. Ryszka, B. Dolińska, K. Czyż, M. Jelińska, A. Strabel, and J. Bocheńska, "Effect of Recombinant Human Prolactin Addition to Biolasol Solution on Biochemical Indicators in Perfundates of Porcine Kidneys," Transplantation Proceedings, vol. 48, no. 5, pp. 1824-1828, 2016.

[21] G. Budziński, R. Wiaderkiewicz, A. Caban et al., "Evaluation of apoptosis in the liver preserved by simple hypothermia using histidine-tryptophan-ketoglutarate and prolactinmodified histidine-tryptophan- ketoglutarate solution," Transplantation Proceedings, vol. 43, no. 8, pp. 2900-2902, 2011.

[22] N. A. Rivero-Segura, E. Flores-Soto, S. García de la Cadena et al., "Prolactin-induced neuroprotection against glutamate excitotoxicity is mediated by the reduction of [Ca2+]i overload and NF- $\kappa$ B activation," PLoS ONE, vol. 12, no. 5, Article ID e0176910, 2017.

[23] E. Weimann, E. Baixeras, N. Zamzami, and P. Kelly, "Prolactin blocks glucocorticoid induced cell death by inhibiting the disruption of the mitochondrial membrane," Leukemia Research, vol. 23, no. 8, pp. 751-762, 1999.

[24] I. Jochmans, E. Lerut, J. Van Pelt, D. Monbaliu, and J. Pirenne, "Circulating AST, H-FABP, and NGAL are early and accurate biomarkers of graft injury and dysfunction in a preclinical model of kidney transplantation," Annals of Surgery, vol. 254, no. 5, pp. 784-791, 2011.

[25] Z. Li, A. Nickkholgh, X. Yi et al., "Melatonin protects kidney grafts from ischemia/reperfusion injury through inhibition of NF-kB and apoptosis after experimental kidney transplantation," Journal of Pineal Research, vol. 46, no. 4, pp. 365-372, 2009.

[26] P. Wingenfeld, U. Gehrmann, S. Strübind, T. Minor, W. Isselhard, and D. V. Michalkl, "Long-Lasting Hypoxic Preservation of Porcine Kidney Cells," in Taurine 2, vol. 403 of Advances in Experimental Medicine and Biology, pp. 203-212, Springer US, Boston, MA, 1996.

[27] X. Guan, G. Dei-Anane, H. Bruns et al., "Danshen protects kidney grafts from ischemia/reperfusion injury after experimental transplantation," Transplant International, vol. 22, no. 2, pp. 232-241, 2009.

[28] E. Kulczykowska, "A review of the multifunctional hormone melatonin and a new hypothesis involving osmoregulation," Reviews in Fish Biology and Fisheries, vol. 11, no. 4, pp. 321-330, 2001.
[29] S. Thébault, "Potential mechanisms behind the antioxidant actions of prolactin in the retina," Experimental Eye Research, vol. 160, pp. 56-61, 2017.

[30] J. Cai, W. Sun, and S. C. Lu, "Hormonal and cell density regulation of heaptic $\gamma$-glutamylcysteine synthetase gene expression," Gastroenterology, vol. 108, no. 4, p. A1043, 1995.

[31] S. K. Kim, "Insulin Signaling Regulates -Glutamylcysteine Ligase Catalytic Subunit Expression in Primary Cultured Rat Hepatocytes," The Journal of Pharmacology and Experimental Therapeutics, vol. 311, no. 1, pp. 99-108, 2004.

[32] C. M. Deaton and D. J. Marlin, "Exercise-associated oxidative stress," Clinical Techniques in Equine Practice, vol. 2, no. 3, pp. 278-291, 2003.

[33] N. Lloberas, J. Torras, I. Herrero-Fresneda et al., "Postischemic renal oxidative stress induces inflammatory response through PAF and oxidized phospholipids. Prevention by antioxidant treatment," The FASEB journal : official publication of the Federation of American Societies for Experimental Biology, vol. 16, no. 8, pp. 908-910, 2002.

[34] M. Boratyńska, D. Kamińska, and O. Mazanowska, "Prevention and therapy of ischemia-reperfusion injury in renal transplantation," Postpy higieny i medycyny doświadczalnej, vol. 58, pp. 9-17, 2004.

[35] A. Ostróka-Cieślik, B. Dolińska, and F. Ryszka, "Influence of antioxidants on the stability of Biolasol ${ }^{\circledR,}$, Acta Poloniae Pharmaceutica. Drug Research, vol. 74, no. 4, pp. 1215-1220, 2017.

[36] T. Asrat and M. P. Nageotte, Acute renal failure in pregnancy, Obsteric Intensive Care Manual, 3rd edition, 2011.

[37] F. Ryszka, B. Dolińska, A. Caban et al., "Hepatoprotective effect of prolactin and cysteine contained in perfusion and preservation solutions on porcine liver stored in simple hypothermia," Transplantation Proceedings, vol. 43, no. 8, pp. 2882-2886, 2011. 


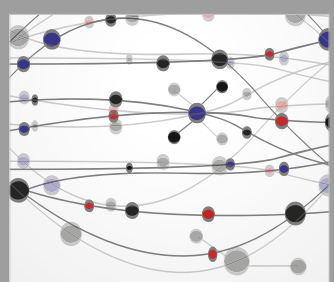

The Scientific World Journal
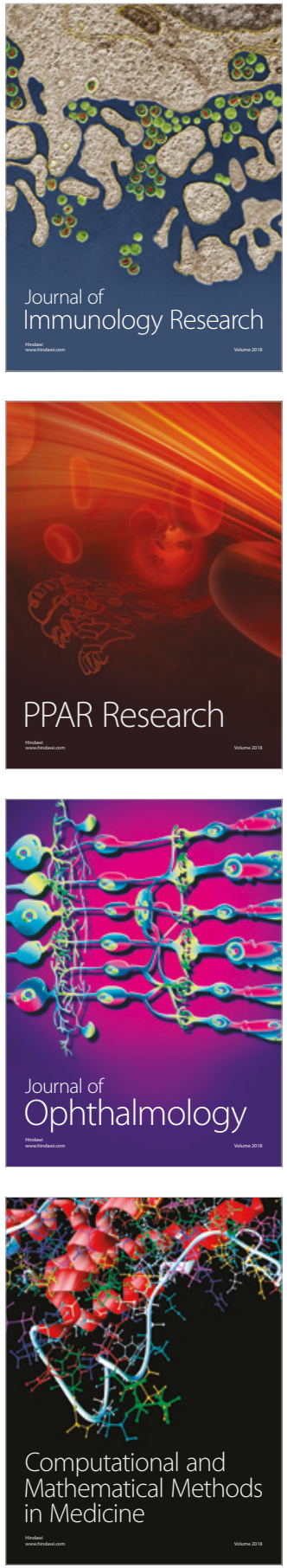

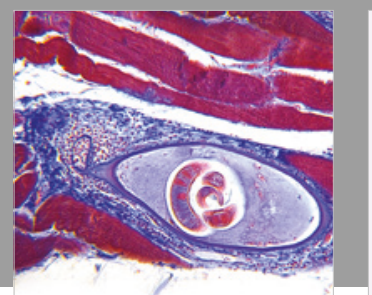

Gastroenterology Research and Practice

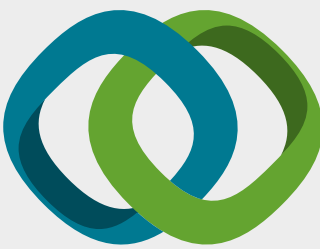

\section{Hindawi}

Submit your manuscripts at

www.hindawi.com
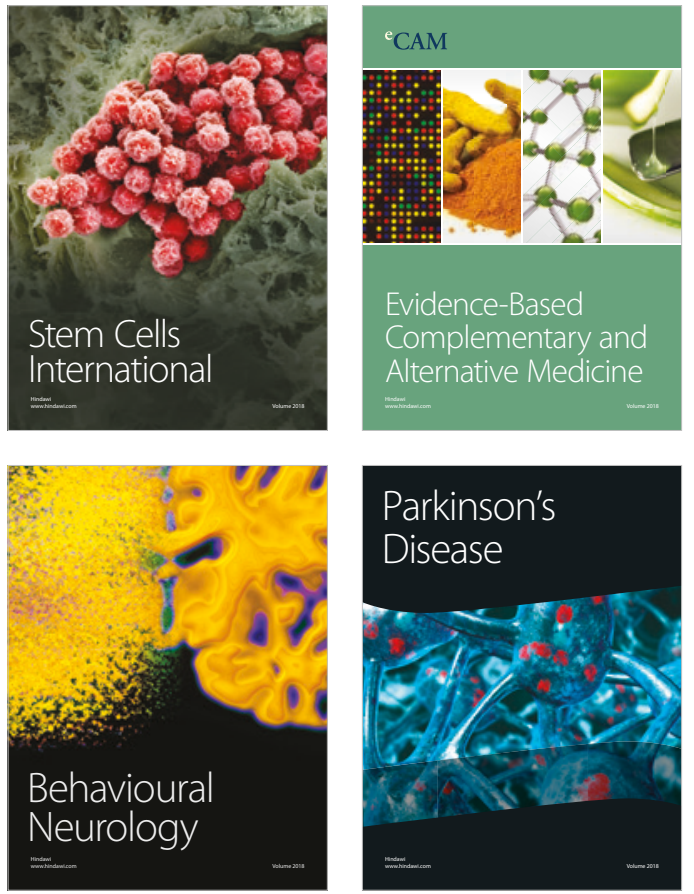

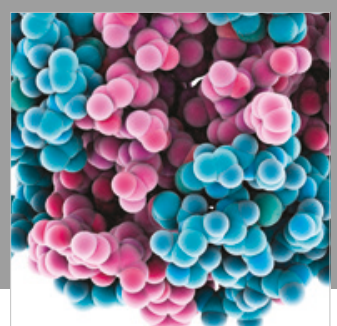

ournal of

Diabetes Research

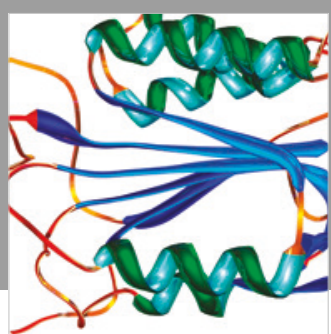

Disease Markers
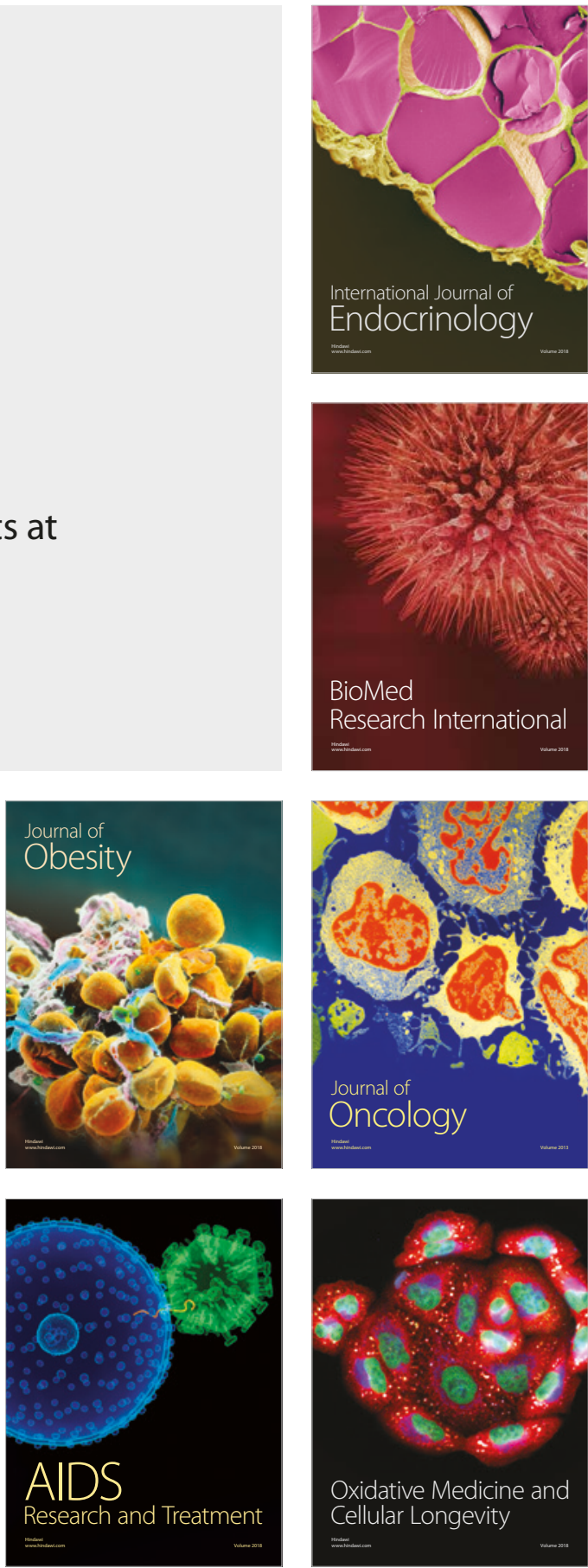